\title{
Erratum to: Sustainable enhancement in yield and quality of rain-fed maize through Gracilaria edulis and Kappaphycus alvarezii seaweed sap
}

\author{
S. Singh ${ }^{1}$ - M. K. Singh ${ }^{1} \cdot$ S. K. Pal ${ }^{1} \cdot$ K. Trivedi ${ }^{2,3} \cdot$ D. Yesuraj ${ }^{3}$ - C. S. Singh ${ }^{1}$ \\ K. G. Vijay Anand ${ }^{3} \cdot$ M. Chandramohan ${ }^{3} \cdot$ R. Patidar $^{3}$ - D. Kubavat ${ }^{2,3}$. \\ S. T. Zodape ${ }^{3}$ - Arup Ghosh ${ }^{2,3}$
}

Published online: 15 January 2016

(C) Springer Science+Business Media Dordrecht 2016

\section{Erratum to: J Appl Phycol \\ DOI 10.1007/s10811-015-0680-8}

The article contains an error in the reference section.

The following reference in original article

Dwivedi SK, Pal A, Meshram MR (2014) Effects of seaweed saps on soil health and productivity of potato (Solanum tuberosum L.). Current Advances in Agricultural Sciences 6:133-137

may be read as

Dwivedi SK, Meshram MR, Pal A, Pandey N, Ghosh A (2014) Impact of natural organic fertilizer (seaweed saps) on productivity and nutrient status of black gram (Phaseolus mungo L.). The Bioscan 9:1535-1539

The online version of the original article can be found at http://dx.doi.org/ 10.1007/s10811-015-0680-8.

M. K. Singh

msisodia_2008@yahoo.com

$\triangle$ Arup Ghosh

arupghosh@csmcri.org

1 Birsa Agricultural University, Jharkhand 834006, India

2 Academy of Scientific and Innovative Research (AcSIR),

CSIR-Central Salt \& Marine Chemicals Research Institute Premises,

G. B. Marg, Bhavnagar 364002, Gujarat, India

3 CSIR - Central Salt and Marine Chemicals Research Institute

Bhavnagar, Gujarat 364002, India 